University of Nebraska - Lincoln

DigitalCommons@University of Nebraska - Lincoln

2000

Details of Extensive Movements by Minnesota Wolves (Canis lupus)

Samuel Merrill

Camp Ripley Headquarters, Little Falls, Minnesota

L. David Mech

USGS Northern Prairie Wildlife Research Center, david_mech@usgs.gov

Follow this and additional works at: https://digitalcommons.unl.edu/usgsnpwrc

Part of the Other International and Area Studies Commons

Merrill, Samuel and Mech, L. David, "Details of Extensive Movements by Minnesota Wolves (Canis lupus)" (2000). USGS Northern Prairie Wildlife Research Center. 76.

https://digitalcommons.unl.edu/usgsnpwrc/76

This Article is brought to you for free and open access by the US Geological Survey at DigitalCommons@University of Nebraska - Lincoln. It has been accepted for inclusion in USGS Northern Prairie Wildlife Research Center by an authorized administrator of DigitalCommons@University of Nebraska - Lincoln. 


\title{
Details of Extensive Movements by Minnesota Wolves (Canis lupus)
}

\begin{abstract}
We used VHF, GPS and satellite radiocollars to study details of long distance movements by four Minnesota wolves (Canis lupus). Number of locations during our tracking ranged from 14 to 274 . Farthest distances reached ranged from $183-494 \mathrm{~km}$, and minimum distances traveled (sums of line segments) ranged from 490-4251 km. Numbers of times wolves crossed state, provincial or interstate highways ranged from 1 to 215 . All four of the wolves returned to or near their natal territories after up to $179 \mathrm{~d}$ and at least two left again.
\end{abstract}

\section{INTRODUCTION}

Some gray wolves (Canis lupus) travel to areas over $800 \mathrm{~km}$ away from their packs (Mech and Frenzel, 1971; Fritts and Mech, 1981; Fritts, 1983; Messier, 1985; Mech, 1987). Until recently it has been technologically or financially difficult to determine the detailed routes of these wolves because of the distances involved. Often, the only information available is the starting point based on where a wolf was originally captured and marked and the ending point based on a capture, road-kill or other type of recovery reported later (Berg and Kuehn, 1982; Ballard et al., 1983; Fritts, 1983; Mech et al., 1995; Wydeven et al., 1995). Recently, however, newer technology such as satellite tracking (Fancy et al., 1988; Ballard et al., 1995) and Global Positioning System (GPS) collars suitable for wolves (Merrill et al., 1998) have yielded detailed descriptions of wolf routes. These more detailed descriptions allow a better understanding of wolf travels and extraterritorial movements and suggest new questions about such movements (Mech, 1995). Using GPS, satellite and aerial VHF telemetry, we provide descriptions of four wolf travel routes.

\section{STUDY AREA}

One wolf in our study left from the east-central Superior National Forest $\left(48^{\circ} \mathrm{N}, 92^{\circ} \mathrm{W}\right)$ in northeastern Minnesota, where the terrain is flat with low ridges and the vegetation consists primarily of cut-over transitional deciduous and boreal forest (Mech, 1987). The area has long been saturated with wolf pack territories (Mech, 1973, 1986). Three other wolves made long extraterritorial movements from a wolf population at Camp Ripley, a 21,400 ha National Guard Training Site in Little Falls, Minnesota $\left(46^{\circ} \mathrm{N}, 95^{\circ} \mathrm{W}\right)$ at the southern edge of wolf range. The terrain is generally flat and the major cover is northern hardwood forest (primarily Quercus, Populus and Betula spp.) interspersed with large open areas (grasslands, wetlands and military firing ranges). Camp Ripley is located at the prairie-forest transition zone of central Minnesota. It is surrounded on the east and south by agricultural lands and on the north and west by forest interspersed with agricultural development.

\section{METHODS}

Male wolf 2480 ( $\geq 18$-mo old; ages estimated by tooth wear) was live-trapped in a modified steel foottrap on 1 November 1972, anesthetized, collared with a $540 \mathrm{~g}$ standard VHF radio-collar and aerially radio-tracked weekly (Mech, 1974). He was a member of a pack of 12 wolves that lived $20 \mathrm{~km}$ west of Ely, Minnesota.

On 3 February 1998 male wolf 5399 ( $\geq 18$-mo old) born at Camp Ripley was captured by helicopter net-gunning. A $920 \mathrm{~g}$ GPS collar (Merrill et al., 1998) was placed on the wolf and the wolf was released. The collar had been programmed to acquire a GPS location every $3 \mathrm{~h}$. If no location was recorded, the GPS collar tried again in $15 \mathrm{~min}$ and $30 \mathrm{~min}$. If all three attempts failed, further attempts were not made until the next programmed interval. We dropped the collar off the wolf via remote signal (Mech et al., 1990), homed in on its VHF signal, collected the collar and downloaded the data (Merrill et al., 1998).

A $560 \mathrm{~g}$ satellite collar with a stiff external whip antenna (Microwave Telemetry Inc., Columbia, Maryland) was placed on male wolf 7803 (10-mo old), which had been captured by helicopter netgunning at Camp Ripley on 1 February 1998. After retrieval and refurbishing, the collar was placed on female wolf 7804 (2-y old; aged by following her with a VHF radio since she was a pup) on 3 February 1999. With both wolves, the collar was programmed for the following duty cycle: first 5 mo, $12 \mathrm{~h}$ on (transmitting a signal), $24 \mathrm{~h}$ off; remainder of collar life, $12 \mathrm{~h}$ on, $72 \mathrm{~h}$ off. ArcView(C) geo- 


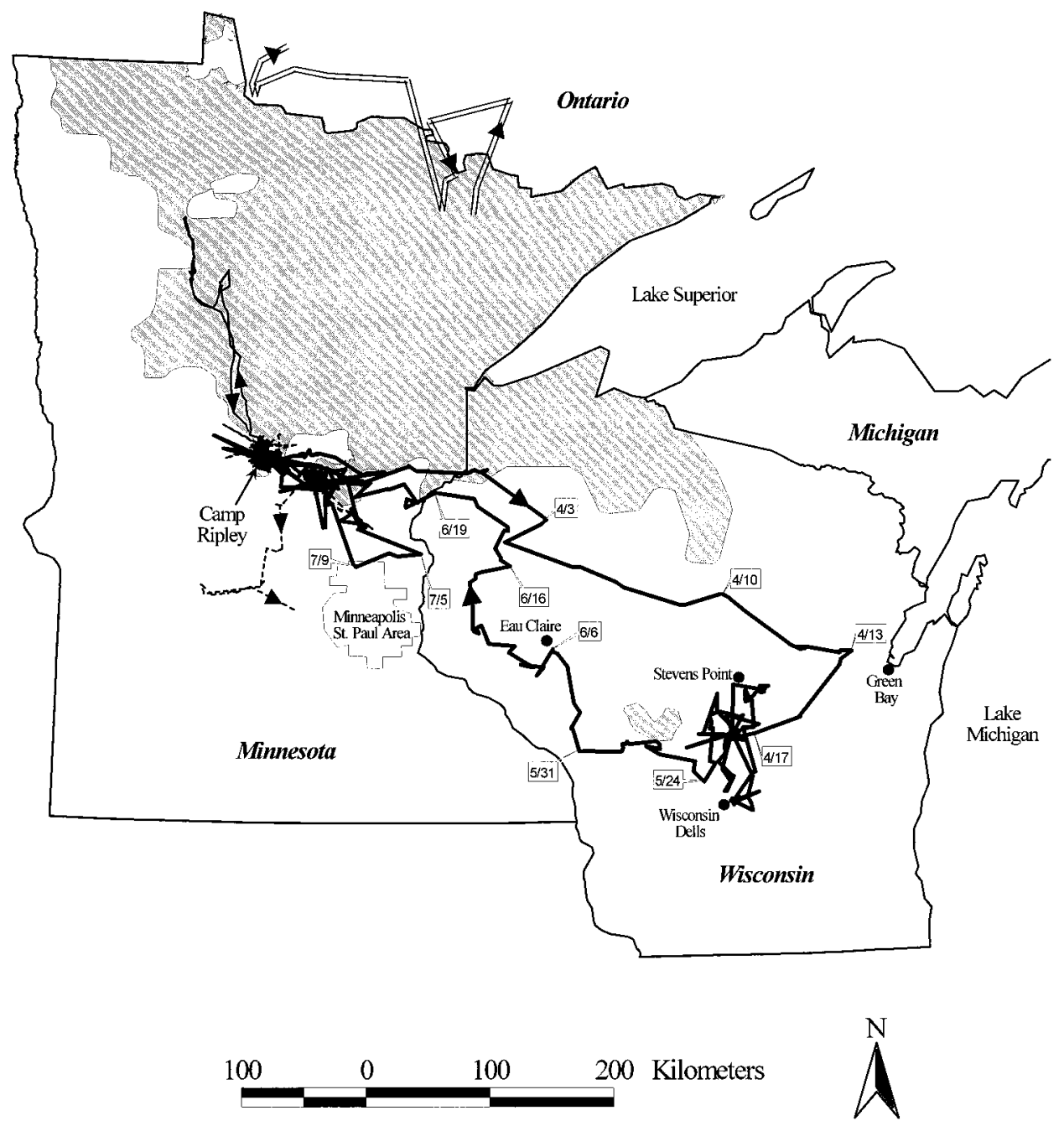

FIG. 1.-Long-distance travel routes of four wolves collared in Minnesota. Double line = wolf 2480, thin single line $=$ wolf 5399 , dashed line $=$ wolf 7803 (killed), thick solid line $=$ wolf 7804 (killed). Shaded area represents 1998 range of breeding wolves

graphic information system (ESRI Inc., Redlands, California) was used to create maps and calculate distances traveled and the number of times wolves crossed state, provincial and interstate highways.

\section{Results}

We located wolf 2480 at 28 locations in his pack territory from 13 November 1972 through 21 March 1973; then on 26 March 1973 the wolf was located $12 \mathrm{~km}$ north of his territory, his first extraterritorial location. After that, the wolf was located 17 times through 30 June 1973 away from his pack's territory and traveled almost exclusively through wilderness (we recorded only one highway crossing). He returned to within $8 \mathrm{~km}$ of his pack territory after $1 \mathrm{mo}$ (Fig. 1). Because of the infrequent radio-tracking, 
wolf 2480 could well have visited the pack without our having detected it. We do not know if the first trip was a predispersal foray or an actual dispersal.

After 19 April 1973 wolf 2480 moved north again and then west through Ontario to a more open area (17 May 1973) with more roads and humans and eventually to the east shore of Lake-of-theWoods. He traveled northeastward parallel with the shore for about $40 \mathrm{~km}$ and then the signal emanated from the same location for $2 \mathrm{wk}$, so a ground check was made. The collar was found by itself, with no indication of what happened to the wolf.

Satellite-collared wolf 7803 left his territory on 12 September 1998 headed directly away from the known wolf breeding range (Fig. 1). His collar collected 55 locations during movements through agricultural areas before he was shot by a coyote (Canis latrans) hunter near Howard Lake, MN on 14 November 1998. He made at least 33 highway crossings. Wolf 7804, also satellite-collared, left on 26 March 1999; during her travels the wolf stopped directional movement for $37 \mathrm{~d}$ between Wisconsin Dells and Stevens Point (Fig. 1). This area includes several rugged wetlands with low human presence. The collar collected 274 locations by 21 September, when the wolf returned to Camp Ripley. On 25 September the wolf left again, settled about $40 \mathrm{~km}$ east of Camp Ripley and was killed illegally on about 11 November 1999. She made at least 215 highway crossings.

The GPS collar on male wolf 5399 collected 1121 locations on 57 days of the animal's extraterritorial trips. The wolf left the territory on 31 May 1998 and traveled an average of at least $3.55 \mathrm{~km} / \mathrm{h}(\mathrm{n}=$ 220 line segments) during his trip. He made at least 17 highway crossings. He returned to near his natal territory and, therefore, we considered the long movement an extraterritorial foray (Messier, 1985). The wolf may have rejoined the pack shortly after the collar was dropped.

No data are available that would allow an estimate of the proportion of wolves in the populations studied that make long distance moves because: (1) with one wolf (2480), a special effort was made to follow it wherever it went, whereas no such effort was made for other wolves in that study, (2) wolf 5399 was part of a very small sample on which GPS collars were tested (Merrill et al., 1998) and (3) with the last two wolves (7803 and 7804), a special effort was made to select predispersal individuals (nonalpha, at least 1-y old wolves) on which to place the satellite collars.

\section{DiscusSION}

The four wolves studied all traveled far from their pack territories. Wolves 7803 and 7804 left the territories in which they were born. Although we were unable to document that the other two wolves were born into the packs whose territories they left, that is likely the case (Fritts and Mech, 1981; Mech, 1987; Fuller, 1989; Gese and Mech, 1991).

All four wolves also returned to their territories or nearby after travels as far away as $494 \mathrm{~km}$ and periods up to $179 \mathrm{~d}$. Two of the four then left again; one remained about $40 \mathrm{~km}$ from its territory for 9 wk (wolf 7804, 7/29-9/21); we could not follow the fourth wolf after its return. Wolves returning to their natal territories after long periods away have been documented before (Fritts and Mech, 1981; Messier, 1985; Mech, 1987; Mech and Seal, 1987; Fuller, 1989).

In two cases, the wolves we followed made large loops to return, whereas one wolf (wolf 5399) returned on almost the same route by which it had left (Fig. 1). The loop returns suggest that even at distances of $494 \mathrm{~km}$ from their territory and for absences as long as $179 \mathrm{~d}$, wolves remember their territory location. This finding extends earlier work showing that wolves moved as far as $63 \mathrm{~km}$ from their capture points for as long as $24 \mathrm{~d}$ can return (Fritts et al., 1984).

Several remaining questions about distant wolf travels include "What constitutes wolf travel barriers?," "Are there travel corridors (Hobbs, 1992) that wolves favor?," and "To what extent do wolf populations adapt to travel barriers and corridors?" (Mech, 1995). With aerial VHF telemetry, relatively few locations are obtainable during long wolf travels (Table 1), so these questions are difficult to address. Satellite and GPS telemetry, however, provide the first opportunity to examine these questions in greater detail.

Studies reviewed by Fuller (1989) report high, human-caused, wolf mortality rates. Much of this mortality was from motor vehicles, suggesting that roads can hinder wolf travel. In our study, however, collared wolves safely crossed major highways. Three of the four wolves studied (7803, 7804 and 5399) crossed numerous interstate highways and many more smaller roads during their travels. This behavior supports findings that wolves in the Midwest are rapidly adapting to human presence (Thiel et al., 


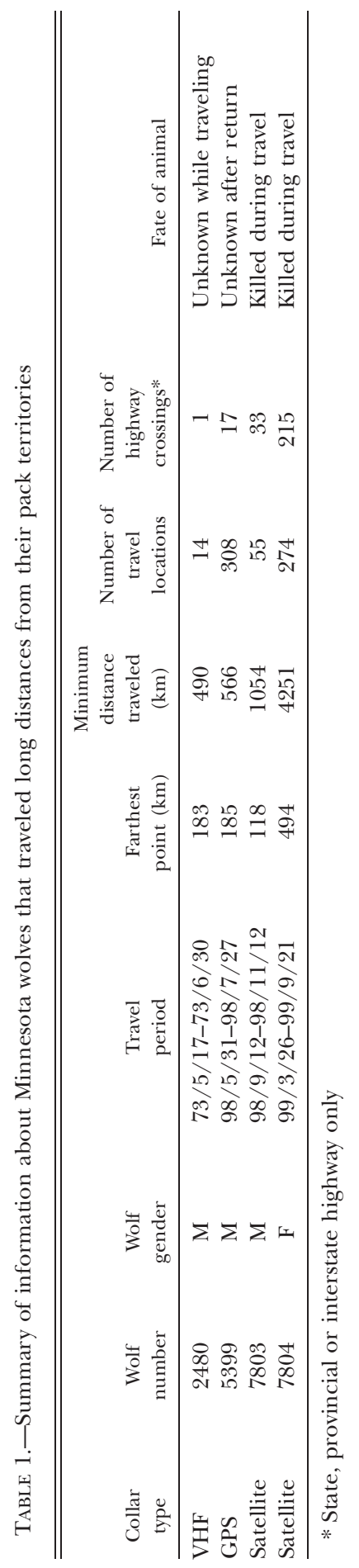


1998). The fourth wolf (2480) traveled mostly through wilderness, likely encountering few human structures. Nevertheless, the long distances the other wolves traveled through mostly human-dominated landscapes illustrate that few structures or landscape features could be considered travel barriers for these wolves. Roads will continue to pose risks to any wolves crossing them, but their function as travel barriers is perhaps more a question of probability than of permeability.

Acknowledgments.-Support for this project was provided by the Minnesota Department of Military Affairs; Minnesota Department of Natural Resources; the Special Projects Foundation, Minneapolis; the U.S. Geological Survey; the U.S. Department of Agriculture North Central Research Station; and the Prairie Wind Middle School Eyes on Wildlife Program. We also appreciate field assistance of W. E. Berg, J. Brezinka, B. Brown, S. H. Fritts, M. Skoglund, P. Watt and P. Wolf and GIS support from C. Erickson and G. Swenson.

\section{Literature Cited}

Ballard, W. B., R. Farnell and R. O. Stephenson. 1983. Long distance movement by gray wolves, Canis lupus. Can. Field-Nat, 97:333.

Ballard, W. B., D. J. Reed, S. G. Fancy and P. R. Krausman. 1995. Accuracy, precision, and performance of satellite telemetry for monitoring wolf movements, p. 461-467. In: L. N. Carbyn, S. H. Fritts and D. R. Seip (eds.). Ecology and conservation of wolves in a changing world. Canadian Circumpolar Institute, Edmonton, Alberta, Occ. Publ. 35.

BerG, W. E. AND D. W. KueHn. 1982. Ecology of wolves in northcentral Minnesota, p. 4-11. In: F. H. Harrington and P. C. Paquet (eds.). Wolves of the world: Perspectives of behavior, ecology and conservation. Noyes Pub., Park Ridge, New Jersey. 474 p.

Fancy, S. G., L. F. Pank, D. C. Douglas, C. H. Curby, G. W. Garner, S. C. Amstrup and W. L. Regelin. 1988. Satellite telemetry: a new tool for wildlife research and management. U.S. Fish and Wildl. Serv. Resour. Publ. No. 172. 54 p.

FRITTS, S. H. 1983. Record dispersal by a wolf from Minnesota. J. Mammal., 64:166-167.

AND L. D. MEch. 1981. Dynamics, movements, and feeding ecology of a newly protected wolf population in northwestern Minnesota. Wildlife Monogr., No. 80:1-79.

Fuller, T. K. 1989. Population dynamics of wolves in North-Central Minnesota. Wildlife Monogr., No. 105:1-41.

HobBs, R. J. 1992. The role of corridors in conservation: Solution or bandwagon? Trends Ecol. Evol., 7:389-92.

MECH, L. D. 1987. Age, season, and social aspects of wolf dispersal from a Minnesota pack, p. 55-74. In: B. D. Chepko-Sade and Z. Halpin (eds.). Dispersal patterns. University of Chicago Press, Chicago. 342 p.

1995. What do we know about wolves and what more do we need to learn?, p 537-545. In: L. N. Carbyn, S. H. Fritts and D. R. Seip (eds.). Ecology and conservation of wolves in a changing world. Canadian Circumpolar Institute, Edmonton, Alberta, Occ. Publ. 35.

- AND L. D. FrenzeL, JR. 1971. Ecological studies of the timber wolf in northeastern Minnesota. USDA For. Serv. Res. Pap. NC-52. N. Cent. For. Expt. Sta., St. Paul, Minnesota. 62 p.

—, K. E. Kunkel, R. C. Chapman and T. J. Kreeger. 1990. Field testing of commercially manufactured capture collars on white-tailed deer. J. Wildl. Manage., 54:297-299.

- S. H. Fritts AND D. Wagner. 1995. Minnesota wolf dispersal to Wisconsin and Michigan. Am. Midl. Nat., 133:368-370.

Merrill, S. B., L. G. Adams, M. E. Nelson and L. D. Mech. 1998. Testing releasable GPS collars on wolves and white-tailed deer. Wildl. Soc. Bull., 26:830-835.

Messier, F. 1985. Solitary living and extra-territorial movements of wolves in relation to social status and prey abundance. Can. J. Zool., 63:239-245.

Thiel, R. P., S. B. Merrill AND L. D. Mech. 1998. Tolerance of denning wolves, Canis lupus, to human disturbance. Can. Field-Nat., 112:340-342.

Wydeven, A. P., R. N. Schultz And R. P. Thiel. 1995. Monitoring of a gray wolf (Canis lupus) population in Wisconsin, 1979-1991, p 147-156. In: L. N. Carbyn, S. H. Fritts and D. R Seip (eds.). 
Ecology and conservation of wolves in a changing world. Canadian Circumpolar Institute, Edmonton, Alberta, Occ. Publ. 35.

SAMUEL B. MERRill, Environmental Office, Camp Ripley Headquarters, 15000 Highway 115, LitTle Falls, Minnesota 56345-4173 And L. DAVID MECH ${ }^{1,2}$, U.S. Geological Survey, Northern Prairie Wildlife Research Center, 8711 37th St. S.E., Jamestown, North Dakota, 58401. Submitted 12 October 1999; accepted 21 March 2000.

\footnotetext{
${ }^{1}$ Corresponding author: Telephone: (651) 649-5231; FAX (651) 649-5233; e-mail: mechxoo@tc. umn.edu

${ }^{2}$ Present address: North Central Research Station, 1992 Folwell Ave., St. Paul, Minnesota 55108
} 